\title{
When is a species not a species? Uncoupled phenotypic, karyotypic and genotypic divergence in two species of South African laminate-toothed rats (Murinae: Otomyini)
}

\author{
P. J. Taylor ${ }^{1}$, S. Maree ${ }^{2,3}$, J. van Sandwyk ${ }^{2}$, R. Baxter ${ }^{4}$ \& R. V. Rambau ${ }^{5,6}$ \\ 1 Durban Natural Science Museum, Durban, South Africa \\ 2 Department of Zoology and Entomology, Mammal Research Institute, University of Pretoria, Pretoria, South Africa \\ 3 Molecular Ecology and Evolution Programme, Department of Genetics, University of Pretoria, Pretoria, South Africa \\ 4 Department of Ecology and Resource Management, University of Venda, Thohoyandou, South Africa \\ 5 Evolutionary Genomics Group, Department of Botany and Zoology, Stellenbosch University, Private Bag X1, Matieland 7602 , \\ South Africa \\ 6 DST-NRF Centre of Excellence for Invasion Biology, Stellenbosch University, Private Bag X1, Matieland 7602, South Africa
}

\begin{abstract}
Keywords
Otomyini; Muridae; Otomys; cytogenetics; morphometrics; molecular phylogenetics; cytochrome $b$.
\end{abstract}

\section{Correspondence}

Peter John Taylor, Durban Natural Science Museum, PO Box 4085, Durban 4000,

South Africa. Email:

taylorpeter@durban.gov.za

Editor: Jean-Nicolas Volff

Received 9 September 2008; revised 27

November 2008; accepted 1 December 2008

doi:10.1111/j.1469-7998.2008.00542.x

\begin{abstract}
Chromosomal polytypy, morphological conservatism and absence of data have frustrated the taxonomic revision of two species of southern African-endemic laminate-toothed rats (Otomys irroratus and Otomys saundersiae s.1.). New cytogenetic (G-banding and fluorescence in situ hybridization), DNA sequence [cytochrome $b$ (cyt $b$ ) gene] and geometric morphometric data demonstrate the synonymy of $O$. saundersiae from Grahamstown (Eastern Cape, South Africa) under $O$. irroratus, and the validity of Otomys karoensis from the Fynbos Biome of the Western Cape. Phenotypic dimorphism in pelage colour and cranial morphology in $O$. irroratus from the climatically unpredictable Albany Thicket (= Savanna) Biome of the Eastern Cape results from the retention of allometric paedomorphic traits in some adults (saundersiae morph) but not others. The same paedomorphic traits are associated with speciation and karyotypic and genetic differentiation in $O$. karoensis. Within $O$. irroratus, two phenotypically and genotypically (cyt $b$ divergence $=6.4 \%$ ) divergent lineages correspond with the Fynbos/Albany Thicket and Grassland biomes. Incipient speciation in $O$. irroratus seems to be associated with ecology rather than karyotype.
\end{abstract}

\section{Introduction}

Vlei rats (Otomys Cuvier, 1824), Karoo or ice rats (Myotomys Roberts, 1929) and whistling rats (Parotomys Thomas, 1918) of the murine tribe Otomyini ('laminate-toothed rats') comprise 23 species that are endemic to sub-Saharan Africa (mostly to Afromontane habitats) and are characterized by morphological conservatism but karyotypic diversity (Robinson \& Elder, 1987; Contrafatto et al., 1992a,b,c; Meester et al., 1992; Contrafatto, 1996; Rambau, Elder \& Robinson, 2001; Musser \& Carleton, 2005).

Uncertainty clouds the taxonomic validity of five parapatric cytotypes ('chromosomal races') of Otomys irroratus Brants, 1827 in South Africa (Contrafatto et al., 1992c; Taylor, Contrafatto \& Willan, 1994; Taylor, 2000; Rambau et al., 2001; Engelbrecht et al., 2006). Cytotypes are defined by the variable presence of heterochromatic short arms, pericentric inversions, a centric fusion and variable number of B chromosomes (all of which are unlikely to result in reproductive isolation), as well as an important, complex tandem fusion mutation in the A1 cytotype (Contrafatto et al., 1992c; Rambau et al., 1997; Engelbrecht et al., 2006), which has been shown to cause infertility of hybrids (Pillay, Willan \& Meester, 1995). Cytotypes can be partly distinguished by cranial shape but not by size (Taylor, Kumirai \& Contrafatto, 2004b), and not by allozymes (Taylor et al., 1992), immuno-electro-transfer analysis (Contrafatto et al., 1997) or limited mitochondrial DNA sequences (Maree, 2002). Here we test the taxonomic validity and evolutionary significance of a previously described chromosomal polytypy in $O$. irroratus based on integrated molecular, cytogenetic and morphometric data.

Further confusion surrounds the taxonomic validity and limits of Otomys saundersiae Roberts, 1929, a South Africanendemic, sibling species of $O$. irroratus (but not sister species: Taylor, Denys \& Mukerjee, 2004a), typically associated with the winter-rainfall Fynbos Biome of the Western Cape Province (Otomys saundersiae karoensis Roberts, 1931), but extending (as Otomys saundersiae saundersiae) into summer-rainfall areas of the southern Drakensberg 
foothills (Grassland Biome) and coastal regions of the Eastern Cape (Albany Thicket Biome = Savanna Biome of Rutherford \& Westphal, 1994) (Mucina \& Rutherford, 2006; Fig. 1a and b). The last-mentioned region includes the type locality of $O$. saundersiae, Grahamstown, which is floristically complex, comprising a mosaic of Albany thicket, quartzite fynbos and sub-escarpment savanna vegetation (Mucina \& Rutherford, 2006).

Meester et al. (1986) regarded karoensis to be a subspecies of saundersiae. Taylor, Meester \& Kearney (1993) analysed
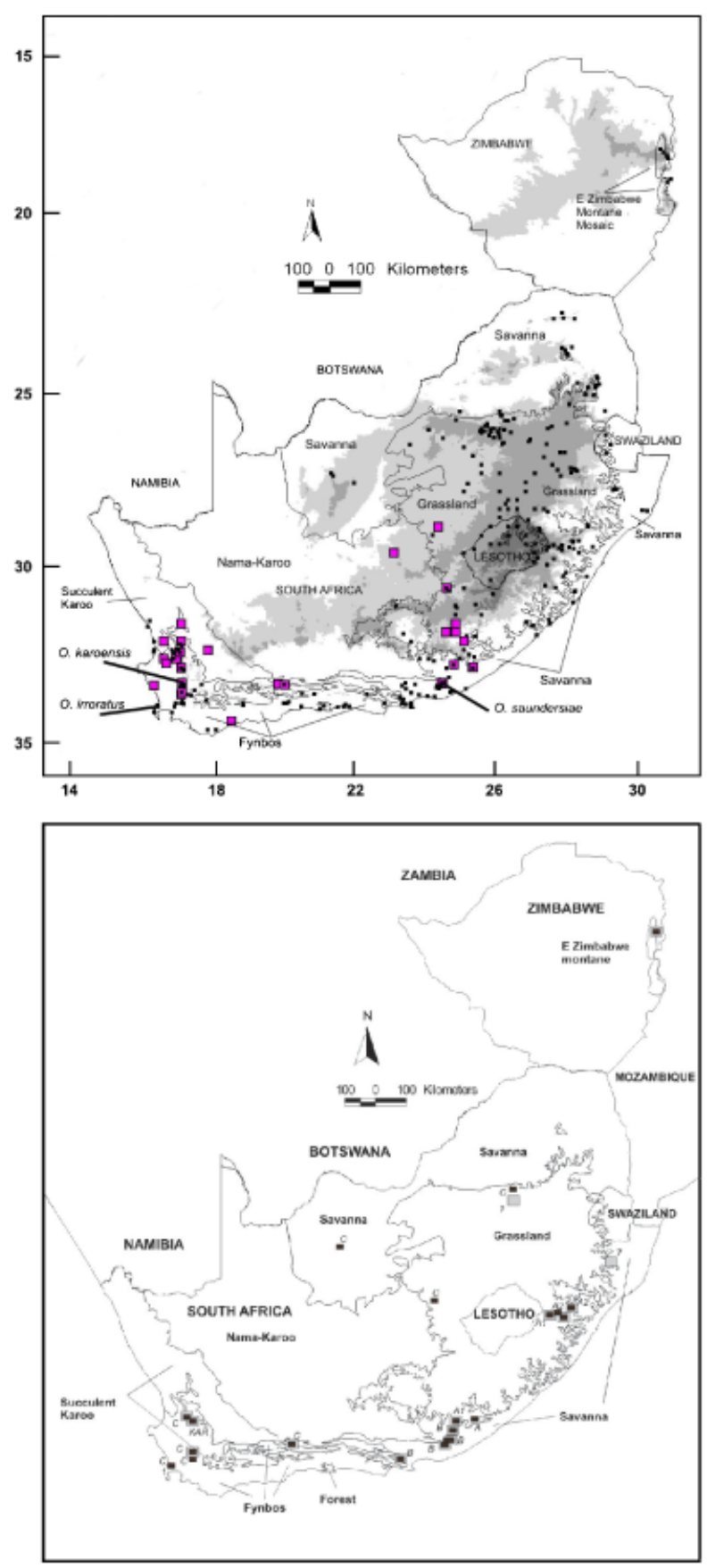

sympatric populations of $O$. irroratus and $O$. s. karoensis (Western Cape) and O.s. saundersiae (Eastern Cape). Based on ecology, pelage colour, body size and cranial morphology, the two species could be distinguished in the Western Cape (Fynbos Biome) and Eastern Cape north of $32^{\circ}$ latitude (Grassland Biome $>1200 \mathrm{~m}$ ), but not in the lowerlying parts $(<1200 \mathrm{~m})$ of the Eastern Cape, south of $32^{\circ}$ (Albany Thicket Biome, including the topotype of $O$. saundersiae). Taylor et al. (1993) recommended including saundersiae as a synonym under irroratus and raising karoensis to species rank. However, in a subsequent morphometric analysis, the holotype and cotype of saundersiae grouped with the holotype of karoensis and not with irroratus; due to ambiguity of the morphometric data, Taylor, Kumirai \& Contrafatto (2005) recommended a combined molecular, morphometric and cytogenetic analysis of topotypic samples of $O$. saundersiae. The second aim of this study was thus to critically test the taxonomic validity of $O$. saundersiae, based on new cytogenetic (G-banding and fluorescence in situ hybridization or FISH), morphometric and molecular [cytochrome $b$ (cyt $b$ ) sequences] data from the topotypic region of $O$. saundersiae.

\section{Material and methods}

\section{Sampling}

Distribution maps of $O$. irroratus and $O$. saundersiae s.l. are shown in Fig. 1a. New molecular, cytogenetic, craniometric and molecular data (Table 1, Fig. 1b) were collected to complement existing molecular (Maree, 2002), cytogenetic (Robinson \& Elder, 1987; Contrafatto et al., 1992c; Contrafatto, 1996; Rambau et al., 2001; Engelbrecht et al., 2006) and morphometric (Taylor et al., 2004b, 2005) databases. Thus, for the first time, multiple complete datasets (cytogenetic, molecular and morphometric) could be analysed for both recognized subspecies of $O$. saundersiae

\footnotetext{
Figure 1 Maps showing the distribution of (a) Otomys irroratus (small squares) and Otomys saundersiae s.l. (large squares) based on 380 unique locality records from the combined collections of the Amathole Museum, Durban Natural Science Museum, Smithsonian Institute and Transvaal Museum, and (b) sample localities for cytogenetically known localities included in geometric craniometric analyses (small squares) and samples for recent molecular data (large squares); in relation to altitude (palest shading 1200-1500 m, mid-grey $1500-2000 \mathrm{~m}$ and dark grey $>2000 \mathrm{~m}$ ), South African Biomes of Rutherford \& Westphal (1994) and the Eastern Zimbabwe Montane Mosaic Ecoregion (Olson et al., 2001). Countries are indicated in capitals while Biome or Ecoregion names are indicated in lower case. The location of type localities for the names $O$. irroratus, $O$. karoensis and $O$. saundersiae are indicated with thick lines. Sample populations of $O$. irroratus are labelled in italics according to their respective cytotypes (A, A1, A2, B and C) in (b) (following Taylor et al., 1994; Taylor, 2000) while the single sampled population of $O$. karoensis is labelled as 'KAR'. Based on unpublished unbanded karyotypes, Zimbabwe populations can be assigned to the 'B' cytotype.
} 
Table 1 Localities and specimens examined for molecular, cytogenetic and geometric craniometric analysis

\begin{tabular}{|c|c|c|c|c|c|}
\hline $\begin{array}{l}\text { Species (field } \\
\text { identification) }\end{array}$ & Cytotype & $\begin{array}{l}\text { Locality and province } \\
\text { (South Africa) }\end{array}$ & Latitude & Longitude & $\begin{array}{l}\text { Museum numbers (TM=Transvaal } \\
\text { Museum; remaining number = Durban } \\
\text { Natural Science Museum), Genbank } \\
\text { numbers (for outgroups) and sex } \\
\text { (M=male; F=female). }\end{array}$ \\
\hline Otomys saundersiae & karoensis & Baines Kloof, W Cape & -33.567 & 19.150 & $* 4883(\mathrm{M})$ \\
\hline \multirow[t]{4}{*}{ karoensis } & karoensis & Constantia, Cape Town, W Cape & -33.967 & 18.483 & 3074(M), 3075(M), 3076(M) \\
\hline & karoensis & Cape Point NR, W Cape & -34.016 & 18.385 & $\overline{7141}(\mathrm{~F}), \overline{7147}(\mathrm{~F})$ \\
\hline & karoensis & Swartberg Mts, W Cape & -33.517 & 22.050 & $\begin{array}{l}\overline{4074}(\mathrm{M}), \overline{407} 6(\mathrm{M}), 4237(\mathrm{M}) \\
\quad 4256(\mathrm{M})\end{array}$ \\
\hline & karoensis & $\begin{array}{l}\text { Uitkyk Pass, Cedarberg Mts, W } \\
\text { Cape }\end{array}$ & -32.411 & 19.096 & 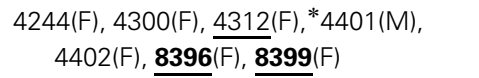 \\
\hline Otomys saundersiae & B & Alice, E Cape & -32.783 & 26.833 & 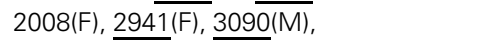 \\
\hline \multirow[t]{3}{*}{ saundersiae s.I. } & B & Groendal NR, E Cape & -33.721 & 25.315 & $8391(F), \overline{8400}(\mathrm{M})-$ \\
\hline & $\mathrm{B}$ & Grahamstown, E Cape & -33.3208 & 26.518 & $\overline{2023}(F), \overline{8349}(M), 8392(M), 8395(M)$ \\
\hline & B & Sam Knott NR, E Cape & -33.112 & 26.682 & $\overline{\mathbf{8 3 8 8}}(\mathrm{F}), \overline{\mathbf{8 3 9 7}}(\mathrm{F}), \mathbf{8 3 9 8 ( \mathrm { M } )}$ \\
\hline \multirow[t]{23}{*}{ Otomys irroratus } & $\mathrm{A} 1$ & Hogsback, E Cape & -32.6 & 27.017 & 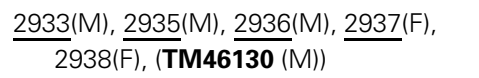 \\
\hline & A1 & Kamberg NR, E Cape & -29.400 & 29.667 & 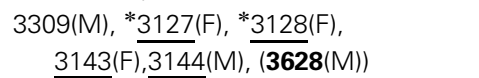 \\
\hline & A1 & Mgeni Vlei NR, KwaZulu Natal & -29.483 & 29.8 & $348 \overline{9(\mathrm{M})}, 34 \overline{90(\mathrm{M})}, 3492(\mathrm{~F})$ \\
\hline & A2 & $\begin{array}{l}\text { Fort Nottingham NR, KwaZulu } \\
\text { Natal }\end{array}$ & -29.417 & 29.917 & $\begin{array}{l}\frac{3487(\mathrm{~F}), * 3496(\mathrm{M}), 3497(\mathrm{M}),{ }^{*} 3575(\mathrm{~F})}{3576(\mathrm{~F})}\end{array}$ \\
\hline & A2 & Karkloof, KwaZulu Natal & -29.317 & 30.2 & $\begin{array}{l}\frac{3125}{3120}(\mathrm{~F}), \\
\left.\left.\frac{(\mathbf{1 8 3 8})}{\mathrm{183}}, \mathrm{*}\right)\right)\end{array}$ \\
\hline & $\mathrm{A} 2$ & Dargle, KwaZulu Natal & -29.502 & 30.033 & $8491(\mathrm{M}), \mathbf{8 4 9 2}(\mathrm{F}),(8483(\mathrm{M})),(8494(\mathrm{M}))$ \\
\hline & A & Stutterheim, E Cape & -29.167 & 30.083 & $\begin{array}{l}{ }^{*} \frac{2911}{2}(\mathrm{~F}),{ }^{* 29292}(\mathrm{~F}), 2923(\mathrm{~F}), 2990(\mathrm{M}), \\
\text { (M), 2992(M), 2993(M), 2994(M) }\end{array}$ \\
\hline & $?$ & $\begin{array}{l}\text { Tygerskloof, } 60 \text { km E Vryheid, } \\
\text { KwaZulu Natal }\end{array}$ & -27.855 & 31.341 & $\begin{array}{l}(\mathrm{TM} \overline{46512}(\mathrm{~F})),(\mathrm{TM} 465 \overline{13}(\mathrm{~F})) \\
\quad(\mathrm{TM} 46522(?))\end{array}$ \\
\hline & $?$ & $\begin{array}{l}\text { Springs Municipal Bird } \\
\text { Sanctuary, Gauteng }\end{array}$ & -26.217 & 28.45 & $($ TM42444 $(\mathrm{F}))$ \\
\hline & B & Sam Knott NR, E Cape & -33.112 & 26.682 & $(8346(M))$ \\
\hline & B & Alice, E Cape & -32.783 & 26.833 & 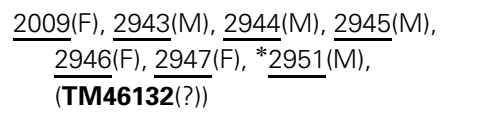 \\
\hline & B & Groendal NR, E Cape & -33.721 & 25.315 & $4322(F),(8625(F))$ \\
\hline & B & Grahamstown, E Cape & -33.321 & 26.518 & $\begin{array}{l}\overline{2010}(\mathrm{M}), \mathbf{8 3 4 6}(\mathrm{M}), \mathbf{8 3 8 9}(\mathrm{F}),(\mathbf{8 6 2 4}(\mathrm{M})), \\
\quad(\mathbf{4 8 2 0}(\text { ?)) }\end{array}$ \\
\hline & C & Bloemfontein, Free State & -29.117 & 26.233 & 3573(F), 3574(M), 3070(M), 3072(M) \\
\hline & $\mathrm{C}$ & Algeria, W Cape & -32.376 & 19.058 & $\overline{4196}(F), \overline{4309}(F), 8390(M),(4317(?))$ \\
\hline & $\mathrm{C}$ & Baines Kloof, W Cape & -33.567 & 19.150 & 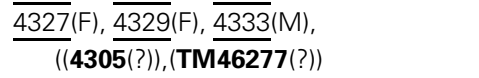 \\
\hline & $\mathrm{C}$ & Constantia, Cape Town, W Cape & -33.967 & 18.483 & $3077(\mathrm{M})$ \\
\hline & $\mathrm{C}$ & Cape Point NR, W Cape & -34.016 & 18.385 & $7134(\mathrm{~F}), \underline{7148(\mathrm{M})}$ \\
\hline & $\mathrm{C}$ & Kuruman, N Cape & -27.45 & 23.43 & *4006(F), 4009(F), $4010(\mathrm{M}), \underline{4501(\mathrm{~F})}$ \\
\hline & $\mathrm{C}$ & Paarl, W Cape & -33.8 & 19.167 & $4307(\mathrm{~F}), \underline{4325(\mathrm{M})}=$ \\
\hline & $\mathrm{C}$ & Rietvlei, Pretoria, Gauteng & -25.817 & 28.533 & $\begin{array}{l}\overline{3058}(\mathrm{~F}), \overline{3061}(\mathrm{~F}), 3566(\mathrm{M}) \\
3057(\mathrm{~F}), 3567(\mathrm{~F})\end{array}$ \\
\hline & $\mathrm{C}$ & Swartberg Mts, W Cape & -33.517 & 22.050 & $421 \overline{0(\mathrm{M})}, 43 \overline{28(\mathrm{~F})}, 4330(\mathrm{M}),(\mathbf{4 3 2 1}(\mathrm{M}))$ \\
\hline & $\mathrm{B} ?$ & $\begin{array}{l}\text { Chingamwe, Inyanga Mts, E } \\
\text { Zimbabwe }\end{array}$ & -18.45 & 32.75 & 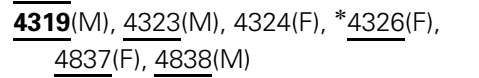 \\
\hline Otomys laminatus & - & $\begin{array}{l}\text { Karkloof Merensky Trust Forest, } \\
\text { KwaZulu-Natal }\end{array}$ & -29.317 & 30.2 & $290 \overline{6(F)}$ \\
\hline Myotomys sloggetti & - & $\begin{array}{l}\text { Lesotho: Sani Pass, } \\
\text { Drakensberg Mts }\end{array}$ & -29.6 & 29.3 & $(5027(\mathrm{M}))$ \\
\hline
\end{tabular}


Table 1. Continued.

\begin{tabular}{|c|c|c|c|c|c|}
\hline $\begin{array}{l}\text { Species (field } \\
\text { identification) }\end{array}$ & Cytotype & $\begin{array}{l}\text { Locality and province } \\
\text { (South Africa) }\end{array}$ & Latitude & Longitude & $\begin{array}{l}\text { Museum numbers (TM=Transvaal } \\
\text { Museum; remaining number = Durban } \\
\text { Natural Science Museum), Genbank } \\
\text { numbers (for outgroups) and sex } \\
\text { (M=male; F=female). }\end{array}$ \\
\hline $\begin{array}{l}\text { Parotomys brantsii } \\
\text { Micaelamys } \\
\text { namaquensis }\end{array}$ & - & Kleinsee, N Cape & -29.683 & 17.083 & $\begin{array}{l}\text { (TM46133(M)) } \\
\text { GenBank AF141215 }\end{array}$ \\
\hline Arvicanthis somalicus & & & & & GenBank AF004574 \\
\hline
\end{tabular}

Gender indicated in parentheses. Both dorsal $(n=109)$ and ventral $(n=97)$ images were analysed (for specimens indicated with asterisks only dorsal views were obtained; for the remainder, both views were obtained). Underlined numbers represent 'adult' specimens (relative toothwear class 4 and 5). Numbers in bold face indicate specimens for which cytochrome b sequences were analysed. Cytotypes were determined either from this study, or Contrafatto et al. (1992a), Rambau et al. (2001). Numbers enclosed in parentheses represent individuals which were not included in morphometric analysis. NR denotes Nature Reserve. Mts denotes Mountains.

(O. s. saundersiae and O.s. karoensis) and for four of the five cytotypes described within O. irroratus (A1, A2, B and C), as well as the geographically isolated Zimbabwe population of $O$. irroratus (assigned to the B cytotype on unbanded chromosomes: Taylor, 2000).

Vlei rats were provisionally identified in the field using general size and pelage coloration and ecological conditions of the capture site (Taylor et al., 1993): O. s. saundersiae (Eastern Cape), intermediate-sized, buffy colour, upper slopes; O. irroratus, larger-sized, dark brown colour, valley bottoms; O. s. karoensis (Western Cape), rocky mountain fynbos habitat, small-sized, pallid and buffy colour. All specimens were deposited in the Durban Natural Science Museum (Table 1).

\section{Cytogenetics and FISH}

Metaphase chromosome slides were prepared from fibroblast tissue cultures that were established from tail biopsies following the protocol of Rambau et al. (2001). Briefly, colcemid $\left(10 \mathrm{mg} \mathrm{mL}^{-1}\right)$ was used to arrest cell division at the metaphase stage and chromosomes were harvested using the hypotonic treatment (0.076 M KCL: Slifer, 1934). Thereafter, cell suspensions were fixed in Carnoy's fixative ( 1 acetic acid:3 methanol), and metaphase chromosome slides were prepared. Chromosome banding was achieved using trypsin digestion (G-banding; Seabright, 1971) in order to identify homologues and barium hydroxide (C-banding, Sumner, 1972) to identify the position of heterochromatin. G-banded karyotypes were numbered and organized according to the size and the position of the centromere following the standard karyotype of $O$. irroratus (Robinson \& Elder, 1987). FISH was performed using flowsorted whole chromosomes of the bush karoo rat (Myotomys unisulcatus, $2 n=28$ ), which were generated for a project focusing on the comparative cytogenetics of the Otomyini (Engelbrecht et al., unpubl. data). The flow-sorted chromosomes were labelled using biotin-16-dUTP (Roche Mannheim, Germany) or digoxigenin-11-dUTP (Roche) using a degenerate oligonucleotide-primed polymerase chain reaction (Telenius et al., 1992). With few exceptions, the FISH protocol broadly followed that of Rens et al. (2006). Metaphase chromosomes were denatured in $70 \%$ formamide at $65^{\circ}$ for $1-2 \mathrm{~min}$, and the probe mixture was denatured in a heating block at $70^{\circ}$ for $10 \mathrm{~min}$. The probes were hybridized for $48 \mathrm{~h}$, and thereafter detected using strepto-avidin cy $3\left(1 \mathrm{mg} \mathrm{mL}^{-1}\right)$ or anti-digoxigenin fluorescein $\left(\alpha\right.$-dig FITC; $\left.1 \mathrm{mg} \mathrm{mL}^{-1}\right)$. Images were captured using a camera fitted on the BX51 Olympus microscope (Tokyo, Japan); G- and C-bandings were captured using bright-field settings and FISH images were captured using fluorescence filters for DAPI, FITC and cy3. Images were merged and analysed using the Genus Cytovision version 3.7 (Applied Imaging Newcastle, UK).

\section{DNA sequencing data analysis}

Sequence alignments were constructed in Clustal X (v 1.82; Thompson et al., 1997). All cyt $b$ sequences displayed an absence of alignment ambiguities and were converted to 381 amino acids in MacClade (version 3.0, Maddison \& Maddison, 1992) to verify the functional reading frame and to test for possible pseudogenes (Esposti et al., 1993; Arctander, 1995). Because substitutional saturation obscures homologous information contained within nucleotide sequences and results in erroneous estimates of genetic distances between taxa (Hillis, 1991, but see Broughton, Stanley \& Durrett, 2000), it was addressed in the present study. The consistency and retention indices (CI and RI) of trees recovered from unweighted parsimony analysis (MP, Kluge \& Farris, 1969) were compared when third position transitions were included, and when they were excluded (Matthee \& Davis, 2001).

Phylogenetic analyses of the cyt $b$ dataset were conducted using maximum likelihood (ML, Felsenstein, 1981), Bayesian (Huelsenbeck \& Ronquist, 2001) and six-parameter weighted parsimony (Williams \& Fitch, 1990) methods to test for congruence among the resulting tree topologies (Hillis, Huelsenbeck \& Cunningham, 1994; Hillis, 1995). Heuristic likelihood and parsimony searches were executed in PAUP* version 4.0b10 (Swofford, 2002) using 100 random taxon additions and TBR branch-swapping. Nodal 
support was assessed by non-parametric bootstrap analysis (Felsenstein, 1985; values $\geq 70 \%$ are considered robust).

Accurate phylogenetic inference relies on the use of adequate and realistic models of sequence evolution (Huelsenbeck \& Rannala, 1997; Kelchner \& Thomas, 2006) and the best-fit overall and codon-specific evolutionary models and model parameters were determined under the Akaike Information Criterion (Akaike, 1974) implemented in Modeltest (v3.06, Posada \& Crandall, 1998). The optimal ML phylogeny was generated using a sequential optimization approach involving successive tree reconstruction and empirical re-estimation of model parameters over all nucleotide sites until the topology and parameters stabilized (Swofford et al., 1996). The starting tree was obtained under the best-fit $\mathrm{GTR}+\mathrm{I}+\Gamma$ model $(\mathrm{Gu}, \mathrm{Fu} \& \mathrm{Li}, 1995)$ and parameter values were estimated by the Modeltest (gamma-shape parameter of among-site rate variation (Yang, 1994), invariable sites, base frequencies and relative substitution rates).

Six-parameter parsimony analysis made use of stepmatrices to assign a rate-specific weight to each of the six nucleotide substitution classes per codon position. Parsimony-based, codon-specific substitution rate $(\mathrm{R})$ matrices were initially calculated under the GTR model (Lanave et al., 1984; Rodriguez et al., 1990), with the optimal ML tree enforced as a topological constraint. These matrices were subsequently converted to proportions and log transformed in EXCEL to produce the stepmatrices (Cunningham, 1997). A $50 \%$ majority rule consensus of minimal-length parsimony trees was produced in PAUP*.

Bayesian analysis was performed in a partitioned manner using MrBayes version 3.1.2 (Huelsenbeck \& Ronquist, 2003). Model parameters were estimated independently (unlinked) under the optimal evolutionary model for each codon position as specified by Modeltest (first position: TRN + I $+\Gamma$, Tamura \& Nei, 1993; second position: HKY, Hasegawa, Kishino \& Yano (1985); third position: GTR + I). Four Markov Chain Monte Carlo chains, each starting from random likelihood trees, ran simultaneously for $5 \times$ $10^{6}$ generations (recording every 100th), and the first $5 \times 10^{5}$ were discarded as 'burn-in' (Huelsenbeck, 2002). Posterior probability values above 0.95 were considered robust.

\section{Divergence date estimation}

The Likelihood Ratio Test (Felsenstein, 1988) was used to test for substitution rate heterogeneity among lineages for a core 19-taxon dataset comprising single representatives of the major lineages identified in the larger phylogeny and the outgroups (Table 1). ML trees were constructed under the GTR $+\mathrm{I}+\Gamma$ model (selected by Modeltest) with a strict molecular clock enforced $(-\ln L=4747.6529)$ and not enforced ( $-\ln L=4737.1372$ ) using PAUP*. A non-significant $(P>0.5) \chi^{2}$ test statistic $(21.04$, d.f. $=17)$ confirmed that a Bayesian approach with a strict clock model was valid. Bayesian analysis (with length $1 \times 10^{7}$, sampled every 1000 iterations with a burn-in of $1 \times 10^{6}$ ) was used to estimate the mean and $95 \%$ confidence limits of nodal dates, assuming the GTR $+\mathrm{I}+\Gamma$ model of nucleotide evolution and the
6 MYA estimation for the origin of the Otomyini (Jansa, Barker \& Heaney, 2006). The analysis was executed using the program BEAST v. 1.4 (Drummond \& Rambaut, 2006a) in conjunction with the programs BEAUti v.1.4 (Drummond \& Rambaut, 2006b) and Tracer v. 1.3 (Rambaut \& Drummond, 2005). To achieve the date calibration, a normal prior $($ mean $=6 \mathrm{MYA}$, standard deviation $=0.2)$ for root height was specified, the mean substitution rate was empirically estimated.

\section{Geometric morphometrics}

Before measurement, every skull was assigned to a relative age class (from 2 to 5) based on skull size and shape, suture development and tooth wear (after Taylor et al., 1993).

Between 97 (ventral image sample) and 109 (dorsal image sample) skulls were selected, comprising specimens from cytogenetically known localities throughout the combined ranges of $O$. irroratus and $O$. saundersiae s.l., including the recently collected material referred to above. For all groups, except the A cytotype and the eastern Zimbabwe montane population, two or more localities with a sample size of three or more were included (Table 1).

Image capture of dorsal and ventral images of the crania was performed using a Sony Cybershot (DSC-H2) digital camera (Tokyo, Japan) with $\times 12$ optical zoom set at two million pixel resolution and mounted on a tripod at a fixed distance from the specimens. The program tpsDig (Rohlf, 1998a) was used for capturing 11 and 15 landmarks on the dorsal and ventral cranial images, respectively.

Size was estimated by centroid size, the square root of the sum of squares of the distances of each landmark from the centroid. Centroid sizes were extracted using the tpsRegr (Rohlf, 1997a) program.

The program tpsRelw (Rohlf, 1997b) was used to conduct generalized procrustes analysis (GPA) superimposition of landmark configurations, and to decompose the GPA residuals into non-uniform (non-affine) and uniform (affine) shape components. To test the allometry of shape differences within and between species, the program tpsRegr (Rohlf, 1997a) was used to regress the dorsal and ventral matrices (affine + non-affine) against centroid size, (Table 2) and toothwear class (relative age) numbers were superimposed on the regression plots. Owing to the demonstrated confounding effect of relative age on species discrimination, we excluded individuals of variant age classes ( 2 and 3 ) from further analysis.

Dorsal and ventral shape matrices comprising 'adult' (age classes 4 and 5) individuals were subject to canonical variates (CV) analyses (with NTSYS-pc: Rolhf, 1997c), in which nine a priori groups were defined [cytotypes A, A1, A2, B and C (Fynbos Biome), C (Grassland Biome), Zimbabwe, O. karoensis and O. cf. saundersiae]. Generalized (Mahalanobis) distances between group means obtained from these analyses were summarized by UPGMA phenograms.

Good introductions to the method and systematic biological application of geometric morphometrics have been 
Table 2 Pearson product-moment correlation coefficients $(r)$ between centroid size (dorsal and ventral) and dorsal and ventral shape variables (partial warps matrix obtained by relative warps analysis of landmark coordinates)

\begin{tabular}{|c|c|c|}
\hline Partial warp & Dorsal $(n=109)$ & Ventral (97) \\
\hline $1 \mathrm{X}$ & 0.127 & $-0.198 *$ \\
\hline $1 Y$ & $0.272 * *$ & $0.280 * *$ \\
\hline $2 X$ & -0.125 & $0.458 * *$ \\
\hline $2 Y$ & $-0.385 * *$ & $-0.232 * *$ \\
\hline $3 X$ & -0.016 & $-0.289 * *$ \\
\hline $3 Y$ & $-0.295 * *$ & $-0.387 * *$ \\
\hline $4 X$ & $0.403 * *$ & -0.036 \\
\hline $4 Y$ & $-0.450 * *$ & 0.153 \\
\hline $5 X$ & $0.441 * *$ & $0.655 * *$ \\
\hline $5 Y$ & 0.018 & $-0.228 *$ \\
\hline $6 x$ & 0.009 & -0.021 \\
\hline $6 Y$ & $0.408 * *$ & -0.163 \\
\hline $7 X$ & 0.153 & $-0.674 * *$ \\
\hline $7 Y$ & 0.099 & $-0.250 *$ \\
\hline $8 X$ & $-0.210 *$ & $0.379 * *$ \\
\hline $8 Y$ & -0.164 & $-0.557 * *$ \\
\hline $9 x$ & $0.302 * *$ & $-0.466 * *$ \\
\hline $9 Y$ & $-0.744 * *$ & -0.185 \\
\hline $10 X$ & $-0.580 * *$ & $0.288 * *$ \\
\hline $10 Y$ & 0.030 & $0.427 * *$ \\
\hline $11 X$ & - & $0.445 * *$ \\
\hline $11 Y$ & - & $0.544 * *$ \\
\hline $12 X$ & - & $0.605 * *$ \\
\hline $12 Y$ & - & $-0.218 *$ \\
\hline Unix & $0.326 * *$ & 0.113 \\
\hline UniY & $-0.505 * *$ & $-0.527 * *$ \\
\hline
\end{tabular}

Statistical significance indicated by, ${ }^{*} P<0.05,{ }^{*} P<0.01$.

provided by Corti (1993), Corti \& Rohlf (2001) and Rohlf (1998b).

\section{Results}

\section{Karyotype analysis}

All karyotypes except $O$. karoensis conformed to previously published work (Robinson \& Elder, 1987; Contrafatto et al., $1992 a, b)$. Because the karyotype of $O$. karoensis has never been published, its chromosomes were arranged based on size as done for $O$. irroratus. The karyotype contains $2 n=28$ chromosomes, and is composed entirely of biarmed chromosomes all possessing heterochromatic short arms. Of the 28 chromosomal pairs, only four pairs could be matched to homologues in the $O$. irroratus karyotype $(O$. karoensis pair 2 corresponds to pair 6 of $O$. irroratus; pair 3 corresponds to pair 3 of $O$. irroratus; pair 4 corresponds to pair 2 of $O$. irroratus; pair 10 corresponds to pair 12 of $O$. irroratus).

\section{G-banding and FISH comparisons}

Comparisons among $O$. karoensis, $O$. irroratus and $O$. $c f$. saundersiae are summarized in Fig. 2 and Supporting Information Fig. S1. All specimens from the topotype
(Grahamstown) of $O$. saundersiae (whether provisionally identified as $O$. irroratus or $O$. saundersiae) had identical karyotypes with a diploid number of $2 \mathrm{n}=28$ (except for one, which had 29 as a result of a supernumerary B chromosome), conforming exactly to the B cytotype of Contrafatto et al. (1992c). All specimens had karyotypes characterized by heterochromatic short arms in the larger chromosome pairs. Side-by-side G-band comparisons of $O$. irroratus and $O$. $c f$. saundersiae, as well as comparison of patterns of hybridization with a complete suite of $M$. unisulcatus whole-chromosome probes (13 autosomes plus the $\mathrm{X}$ ), revealed that they have identical karyotypes (i.e. the B cytotype, as shown in Fig. 2a, c and Supporting Information Fig. S1). Pericentric inversions were detected in both presumed taxa in three autosomal pairs (OIR2, 4 and 6), which appear either as fixed or as floating polymorphisms (data not shown).

Conversely, the FISH results presented in Fig. 2 revealed considerable differences in the karyotypes of $O$. karoensis (OKA) and $O$. irroratus (OIR), as revealed by hybridization patterns with four of the 12 whole chromosomes of $M$. unisulcatus: chromosomes 1 (OUN1), 10 (OUN10), 9 (OUN9) and 11 (OUN11). Myotomys unisulcatus whole chromosomes OUN1 and 10 produced four hybridization signals in $O$. irroratus and five signals in $O$. karoensis, and the two probes form a syntenic association on the distal ends of OIR1 and OKA1. Further, M. unisulcatus chromosome 10 (OUN10) is retained as two chromosomal fragments in $O$. irroratus and three fragments in O. karoensis (Fig. 2a and b). Myotomys unisulcatus chromosomes 9 and 11 hybridized to four and five chromosomal pairs in O. irroratus (OIR1, 2, 7 and 11) and O. karoensis (OKA1, 4, 5, 8 and 13), respectively. Of the four signals obtained on $O$. irroratus, two occur adjacent to each other (OIR11) while in $O$. karoensis the five signals are located on different chromosomes and the syntenic association identified in OIR11 is lost (Fig. 2c and d). G-banding comparisons, as well as comparisons of hybridization patterns of the $O$. unisulcatus chromosome paints (Supporting Information Fig. S1) emphasize further the low degree of homology between $O$. karoensis and $O$. irroratus (including $O$. saundersiae).

\section{Molecular phylogeny inferred from cyt $b$ sequences}

The alignment of cyt $b$ sequences from representatives of the Otomyini and the outgroups, Micaelamys namaquensis and Arvicanthis somalicus, resulted in 1137 aligned sites containing 373 variable and 243 parsimony informative characters (GenBank accession numbers: FJ619536 - FJ619563). Concurrent empirical estimation of GTR $+\mathrm{I}+\Gamma$ model parameters using the optimal ML tree as a fixed topology produced a gamma-shaped parameter of $\alpha=1.9629$, which suggests that all sites evolve at a relatively uniform rate. Estimated mean base frequencies $(\mathrm{A}=0.3170, \mathrm{C}=0.2990$, $\mathrm{G}=0.1183$ and $\mathrm{T}=0.2658)$ indicated a strong bias against G's, consistent with what is documented for mammalian mtDNA (Irwin, Kocher \& Wilson, 1991). No significant 

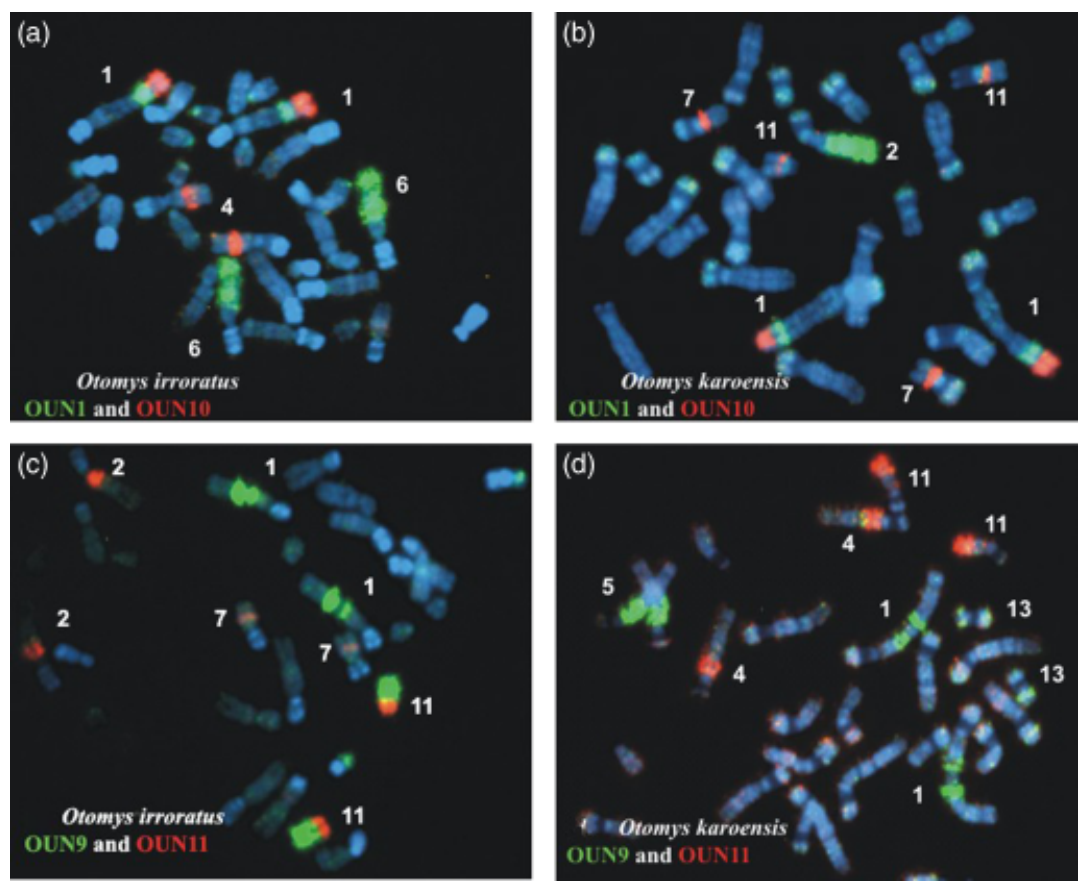

Figure 2 Example of the FISH results showing the differences (and similarities) in karyotypes of Otomys karoensis (DM 8396) and Otomys irroratus (DM8392) that were identified using the Myotomys unisulcatus whole chromosome OUN1, 10, 9 and 11. The chromosomes were labelled with digoxigenin-11-dUTP (OUN1 and OUN9) and biotin-16-dUTP (OUN10 and 11); metaphases were counterstained with DAPI, which fluoresces blue. $(a, b)$ OUN1 and 10 produced four hybridization signals in $O$. irroratus and five signals in $O$. karoensis, and the two probes form a syntenic association on the distal ends of OIR1 and OKA1. Further, M. unisulcatus chromosome 10 (OUN10) is retained as two chromosomal fragments in $O$. irroratus and three fragments in O. karoensis. (c, d) Myotomys unisulcatus chromosome 9 and 11 hybridized to four and five chromosomal pairs in $O$. irroratus (OIR1, 2, 7 and 11) and $O$. karoensis (OKA1, 4, 5, 8 and 13), respectively. Of the four signals obtained on $O$. irroratus two occur adjacent to each other (OIR11) while in $O$. karoensis the five signals are located on different chromosomes and the syntenic association identified in OIR11 is lost.

Table 3 Sequence divergence (uncorrected, $P$ and GTR-corrected distances with empirical parameter estimates of $\alpha$ and plnv; means \pm standard deviation) and estimated absolute ages (MYA) of nodes (Bayesian analysis - BEAST program) for strict clock model and calibration dates for the origin of the Otomyini at 6 MYA (Jansa et al., 2006), based on a reduced dataset of 19 sequences including both outgroups (Arvicanthis somalicus and Micaelamys namaquensis)

\begin{tabular}{|c|c|c|c|c|c|}
\hline \multirow[b]{2}{*}{ Node } & \multirow[b]{2}{*}{ MYA } & \multicolumn{2}{|c|}{$95 \%$ confidence limits } & \multicolumn{2}{|c|}{ Genetic distances } \\
\hline & & Lower & Upper & $P$ & GTR \\
\hline Deepest split within Otomyini (Parotomys-Myotomys-Otomys) & 2.67 & 2.10 & 3.25 & $0.108 \pm 0.009$ & $0.270 \pm 0.035$ \\
\hline (Otomys irroratus (Otomys karoensis-Otomys laminatus)) & 1.61 & 1.24 & 2.00 & $0.086 \pm 0.006$ & $0.155 \pm 0.028$ \\
\hline O. karoensis-O. laminatus & 0.81 & 0.55 & 1.06 & $0.058 \pm 0.004$ & $0.079 \pm 0.008$ \\
\hline $\begin{array}{l}\text { Deepest split within O. irroratus (Albany Thicket + Fynbos) } \\
\text { (Grassland) }\end{array}$ & 1.13 & 0.83 & 1.46 & $0.064 \pm 0.003$ & $0.093 \pm 0.006$ \\
\hline (Karkloof -Zimbabwe-'Highveld') (Drakensberg Mts) & 0.68 & 0.48 & 0.92 & $0.045 \pm 0.001$ & $0.058 \pm 0.002$ \\
\hline (Zimbabwe (Karkloof - 'Highveld')) & 0.50 & 0.32 & 0.70 & & \\
\hline (Albany Thicket)(Fynbos) & 0.25 & 0.15 & 0.37 & $0.019 \pm 0.0006$ & $0.020 \pm 0.0009$ \\
\hline
\end{tabular}

difference in base composition was evident across the lineages examined $\left(\chi^{2}=15.9321 ; P=1.0\right)$. Estimates of cyt $b$ sequence differentiation among the major lineages recovered in the Otomyini phylogeny tree(s) are summarized in Table 3.

Parsimony analyses of the cyt $b$ data indicate that third codon position transitions are saturated. The CI and RI of 32 equally parsimonious trees (793 steps) produced by unordered and unweighted analysis of all characters $(\mathrm{CI}=0.5839, \mathrm{RI}=0.7371)$ were lower than when third position transitions were excluded (eight trees, 283 steps, $\mathrm{CI}=0.7138, \mathrm{RI}=0.7589$ ). These results corroborate previous evidence of marginal saturation at third position transitions of cyt $b$ from 27 Otomyini taxa (Maree, 2002), and from several other murine taxa (Ducroz, Volobouev \& Granjon, 2001; Steppan, Zawadski \& Heaney, 2003). 
Therefore, six-parameter weighted parsimony analysis used a codon-specific weighting strategy that resulted in 1105 most parsimonious trees $(72$ steps, $\mathrm{CI}=0.6443, \mathrm{RI}=$ $0.7550)$.

The optimal ML phylogeny (GTR $+\mathrm{I}+\Gamma$ model; Fig. 3) revealed the monophyly of $O$. irroratus and $O$. karoensis lineages, and a sister relationship for $O$. karoensis and Otomys laminatus with high bootstrap support (also sixparameter MP and Bayesian). All five representatives of O. $c f$. saundersiae grouped within $O$. irroratus. The nodes defining the two major clades (A and B) recovered within the $O$. irroratus complex (which include $O$. cf. saundersiae), and the two subclades within clade B, are well supported. Uncorrected ( $p$-distances) and GTR-corrected distances calculated with empirical parameter estimates of $\alpha$ (1.6929) and pInv (0.5663) are provided in Table 3 and Fig. 3. With the exception of $O$. $c f$. saundersiae, GTR-corrected genetic distances reveal deep divergence (7.0-33.7\%) between recognized species (uncorrected $p$-distances range from $5.2 \%$ to $11.9 \%$ ) and were of a magnitude similar to those separating the individuals from clade A and clade B (corrected, $8.5-10.3 \%$; uncorrected $5.9-6.9 \%$ ).

Estimates of the divergence dates of lineages recovered in the cyt $b$ phylogeny obtained by the BEAST program

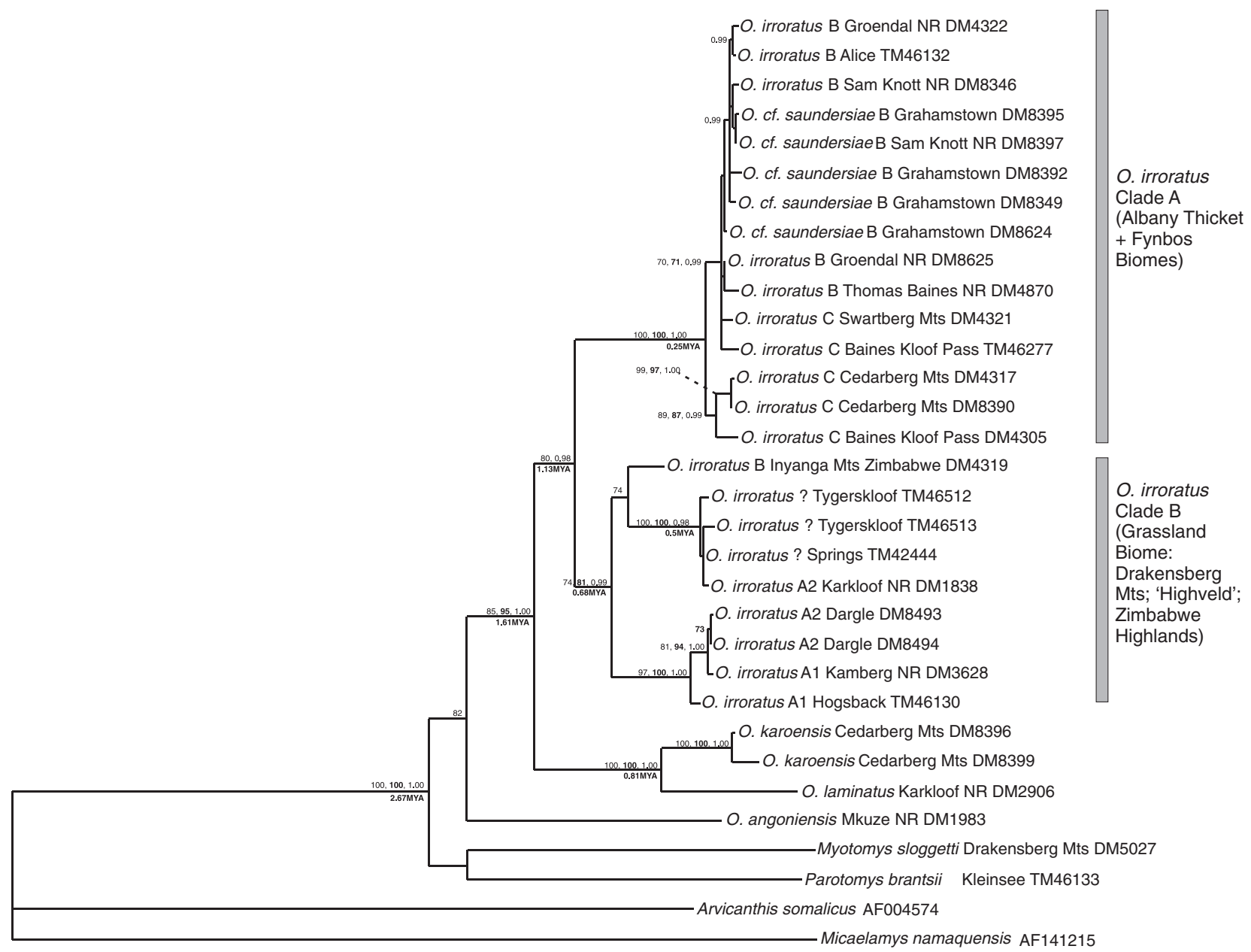

0.1 substitutions per site

Figure 3 The optimal maximum likelihood (ML) phylogeny ( $\ln L=-4993.8027$ ) retrieved under the GTR $+I+\Gamma$ model of evolution from cyt $b$ sequences of 30 representatives of the African Otomyini and outgroups Micaelamys namaquensis and Arvicanthis somalicus. Values above branches refer to bootstrap support ( $\geq 70 \%$ ) obtained for ML (100 replicates, indicated as plain text) and for six-parameter parsimony (1000 iterations, indicated in boldface), and Bayesian posterior probabilities $(\geq 0.95)$ estimated in a partitioned manner under the best-fit evolutionary model for each codon position $\left(5 \times 10^{6}\right.$ generations with $5 \times 10^{5}$ burn-in). The absolute mean dates in MYA (with $95 \%$ confidence limits) obtained from the BEAST program using the 6 MYA calibration for the origin of the Otomyini (Jansa et al., 2006) are given below the branches. Branch lengths are proportional to the extent of evolutionary change along each lineage. The letter following O. irroratus denoted the cytotype where known (? where unknown). 
(means \pm standard deviations) are shown in Table 3 and on certain nodes of the ML phylogeny (Fig. 3). Dating results are discussed below.

\section{Craniometric comparisons}

Our analysis followed a two-step process. Firstly, we explored the role (or confounding effect) of ontogeny on species discrimination. Secondly, we explored geometric craniometric relationships between cytotypes and species in a reduced dataset comprising only 'mature' age class 4 and 5 individuals.

\section{Effect of ontogeny on species discrimination}

Both dorsal and ventral landmark shape datasets (weight matrices obtained from GPA; see 'Material and Methods') were regressed onto centroid size (only dorsal results shown; Fig. 4). In both cases, Wilks' $\lambda$ values obtained were highly significant (dorsal: Wilks' $\lambda=0.23, \quad P \ll 0.001$; ventral: Wilks' $\lambda=0.29, P \ll 0.001)$. Age classes were superimposed on plots of size (centroid size) versus shape (a selected partial warp showing a strong correlation with centroid size)
(Fig. 4). Age class 2 and 3 (younger) individuals were distributed predominantly at low values of centroid size (smallersized) and high values of the shape axes. Thin plate splines shown in Fig. 4 show the shape response to the complete range of centroid size variation in the data; small-sized individuals (O. karoensis and younger individuals of $O$. irroratus and $O$. cf. saundersiae) have a proportionately narrower anterior zygomatic region and inflated braincase, while the reverse is true for large-sized individuals (mature $O$. irroratus).

\section{Morphometric relationships among cytotypes and species}

CV plots of nine cytotype-species groups of 'adults' (toothwear class $4+5$ ) based on shape data (weights matrices) from dorsal (Fig. 5a) and ventral (Fig. 5b) landmarks revealed complete separation of $O$. karoensis and $O$. irroratus based on cranial shape, although individuals fieldidentified as $O$. saundersiae (including those corrected to irroratus by karyotype or cyt $b$ sequences) appear intermediate in skull shape between $O$. karoensis and $O$. irroratus. In both dorsal and ventral plots, however, they grouped

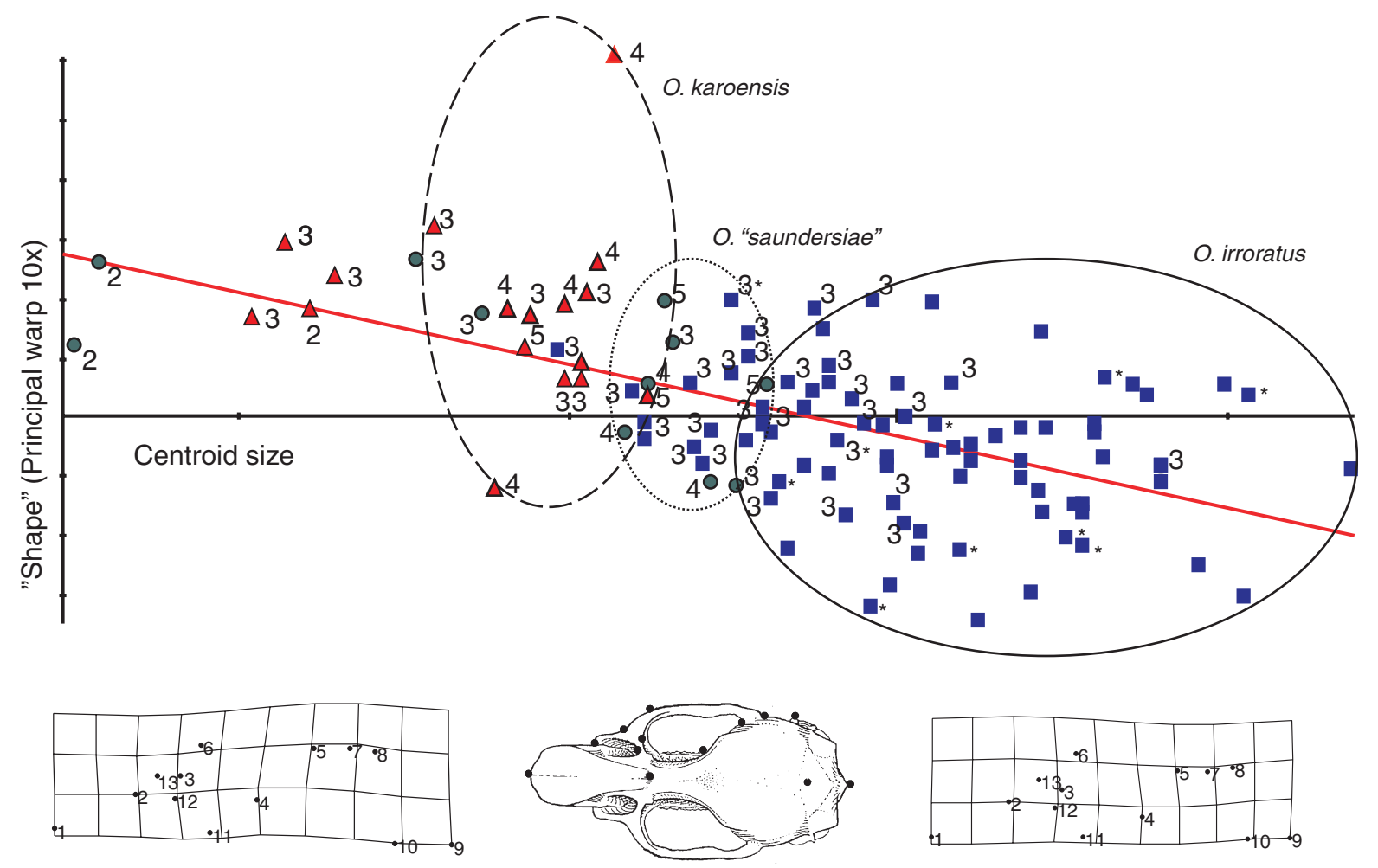

Figure 4 Regression plot of centroid size versus shape (as exemplified by variation in partial warp $10 \times$ ) for dorsal landmark data, showing the distribution of samples of Otomys irroratus (filled squares), Otomys karoensis (filled triangles) and Otomys cf. saundersiae (filled circles). Thin plate splines indicate deformation of landmarks (all affine and non-affine partial warps combined) associated with the range of centroid size variation in the data. Numbers represent toothwear (relative age) classes for $O$. karoensis and O. cf. saundersiae (all un-numbered $O$. irroratus belonged to toothwear class 4 or 5). Individuals of $O$. irroratus marked with asterisks are those from the Savanna Biome of Eastern Cape, which occur sympatrically with individuals of the same species mis-identified as O. saundersiae (filled circles). Circles delimit adult (age class 4 and 5) individuals of the three putative taxonomic groups. 
(a)

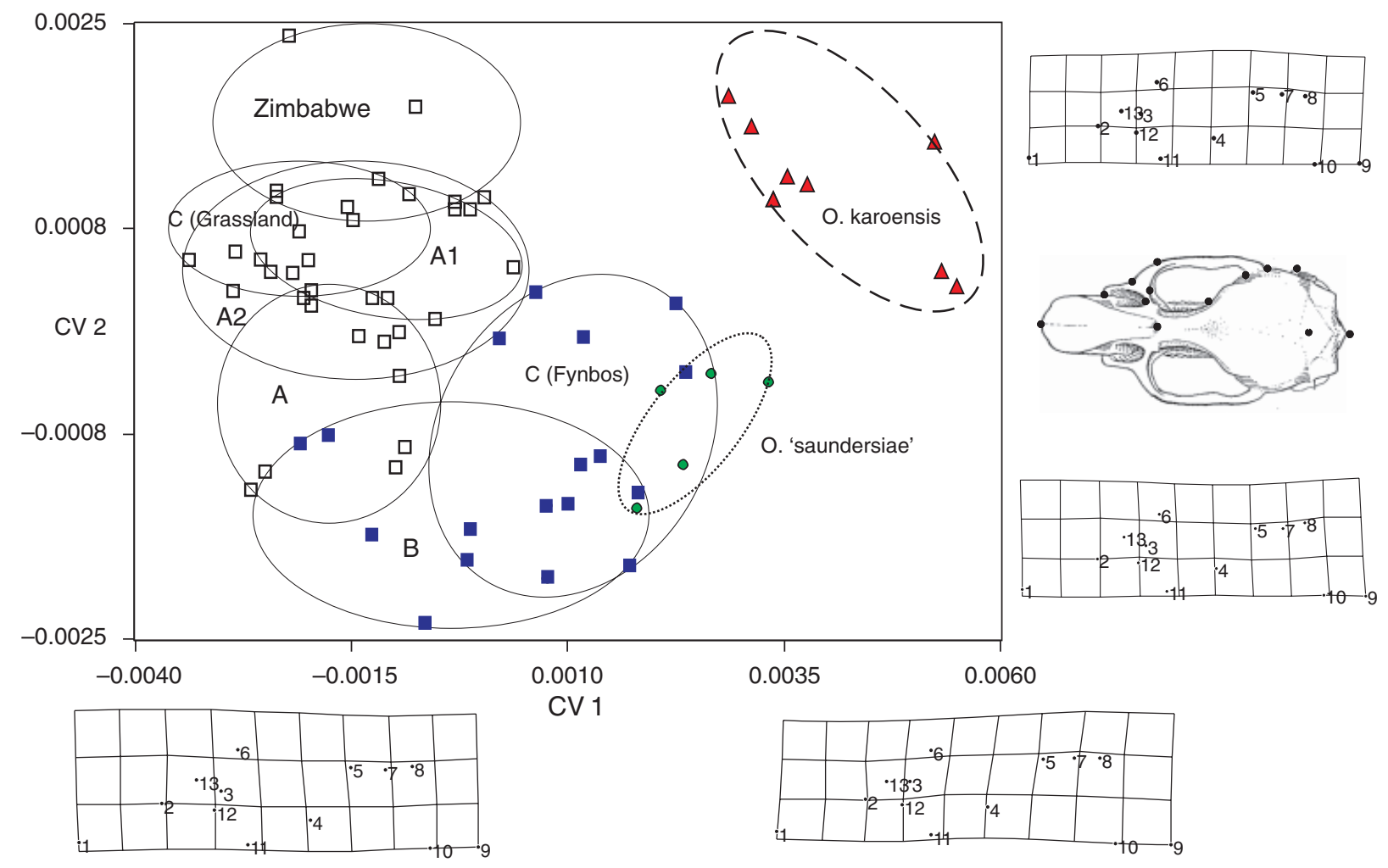

\section{Cytotype/species}

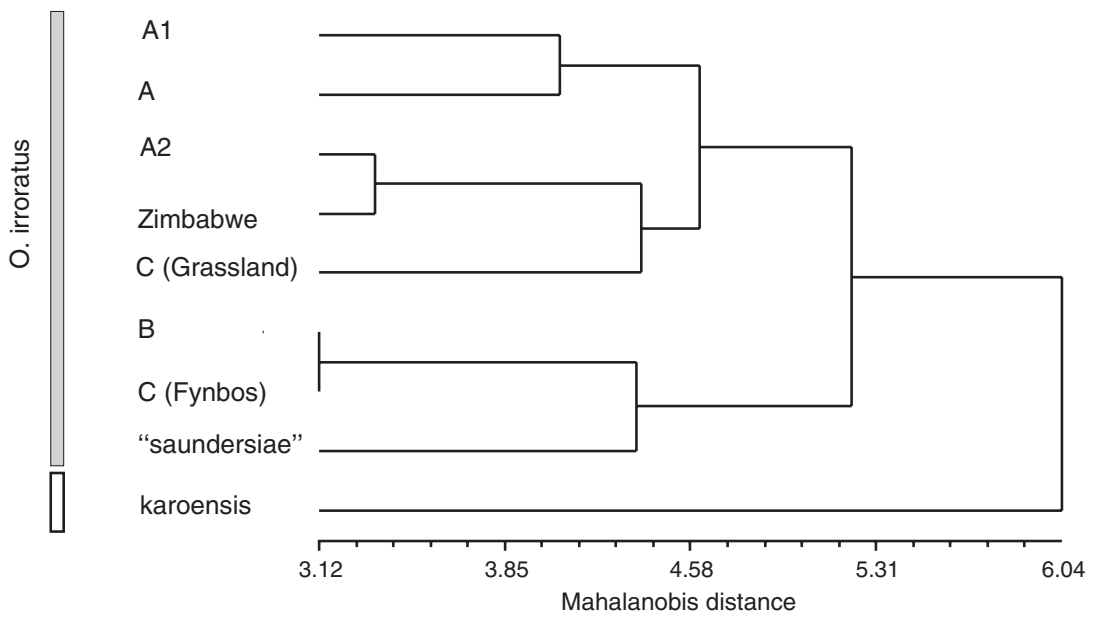

Figure 5 (a) Canonical variates analysis (CVA) of combined weights matrix (affine + non-affine) from generalized procrustes analysis (GPA) of 11 dorsal landmarks for nine pooled cytotype/species samples (combined $n=66$; including only toothwear class 4 and 5 individuals) representing all South African cytotypes and the Zimbabwean population of irroratus in relation to Otomys saundersiae karoensis (filled triangles) and Otomys cf. saundersiae saundersiae (filled circles). Individuals of Otomys irroratus are indicated by open squares for cytotypes A, A1, A2, C (from Grassland Biome) and Zimbabwe populations, and closed squares show cytotype B (Savanna Biome) and cytotype C (Fynbos Biome). Dorsal skull landmark reference points are shown. Phenogram of Mahalanobis distances between group centroids shown below; (b) CVA of combined weights matrix (affine + non-affine) from GPA of 15 ventral landmarks for nine pooled OTUs (combined $n=58$; including only toothwear Class 4 and 5 individuals) representing all South African O. irroratus cytotypes and the isolated Zimbabwe population of irroratus (filled squares) in relation to 0 . s. karoensis (filled triangles) and O. cf. s. saundersiae (filled circles). Ventral skull landmark reference points are shown. Phenogram of Mahalanobis distances between group centroids shown below. 
(b)

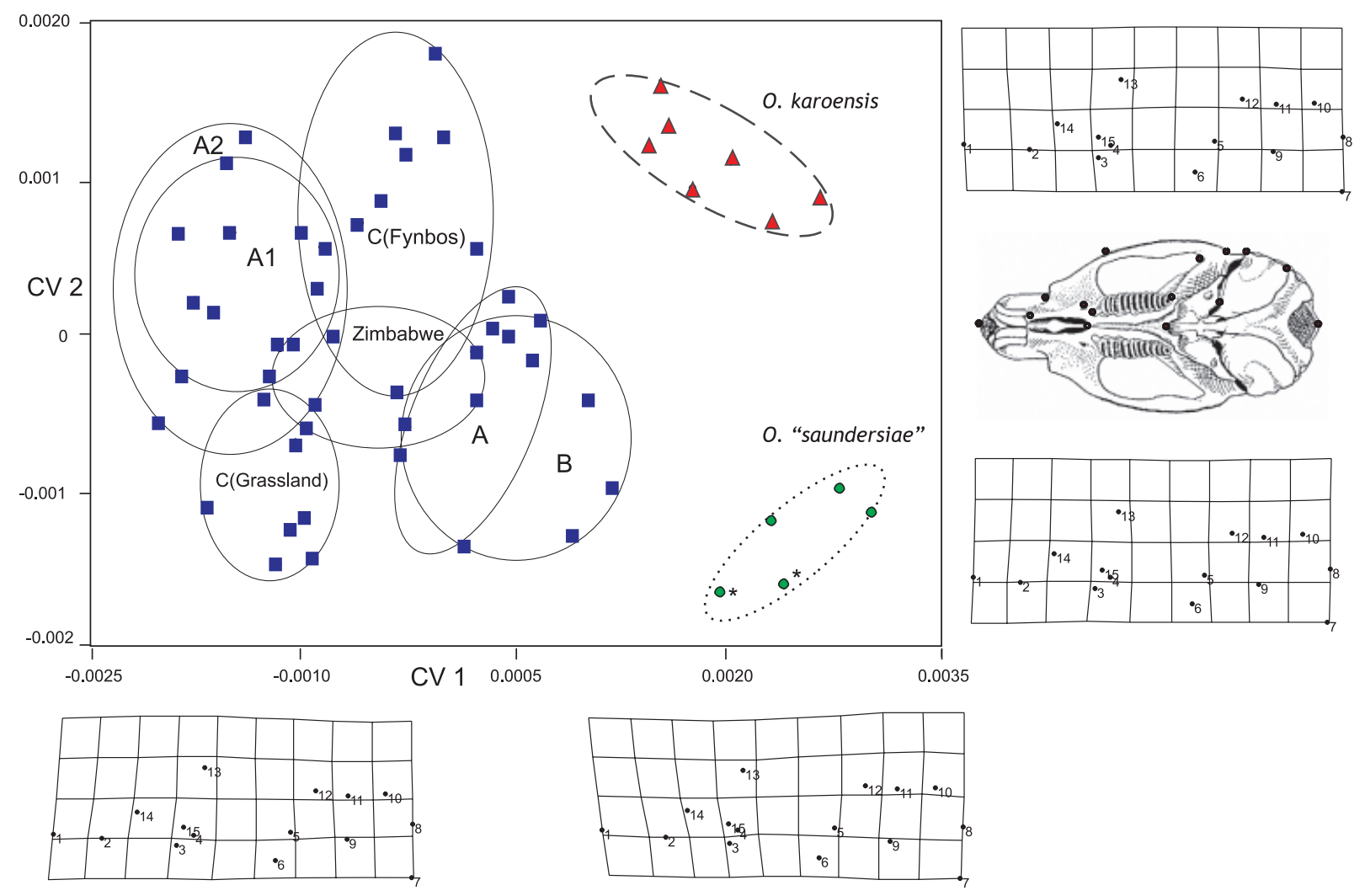

Cytotype/species

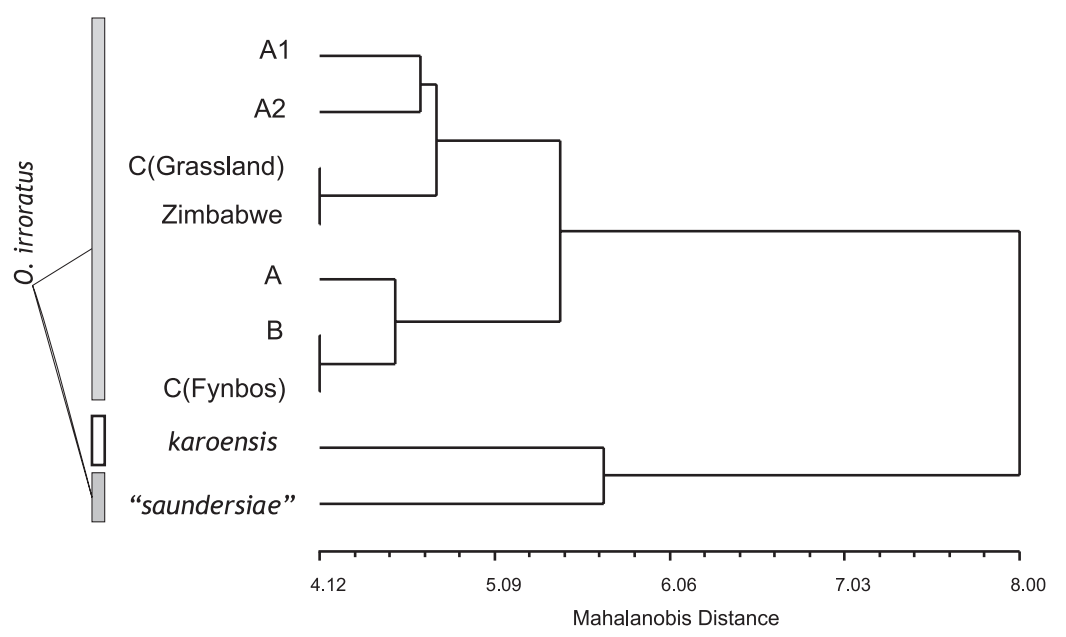

completely separately from the sympatrically occurring B cytotype sample of $O$. irroratus. In the ventral plot, 'saundersiae' adults plot entirely separately from all other individuals, forming a distinct phenon closest to O. karoensis in the Mahalanobis distance phenogram (Fig. 5b). Based on the thin plate spline visualizations associated with the first dorsal CV axis (Fig. 5a), O. karoensis is distinguished from $O$. irroratus in having proportionately shorter and narrower nasal bones, narrower zygomatic arches and a wider braincase (i.e. the identical trend observed due to centroid size variation in Fig. 4). Ventrally (Fig. 5b), O. karoensis possesses incisors that are more backward curving 
(opisthodont) than $O$. irroratus (orthodont); in addition, in $O$. karoensis, the maxillary and zygomatic regions are proportionately narrower, and the bullae are more inflated.

Some craniometric differentiation was observed between groups of cytotype populations of $O$. irroratus. In both dorsal and ventral views, $C$ cytotype populations from the Grassland Biome and Fynbos Biome were completely differentiated (no overlap on CV plots; Fig. 5a and b), grouping with A, A1, A2 and Zimbabwe cytotypes, and the Eastern Cape B cytotype, respectively.

\section{Discussion}

\section{Status of $\boldsymbol{O}$. saundersiae}

Cytogenetic and molecular data refute the taxonomic validity of $O$. saundersiae, which matches in karyotype and cyt $b$ sequence the B cytotype of $O$. irroratus, and not $O$. karoensis, which formerly has been included erroneously as a subspecies of $O$. saundersiae. More importantly, the chromosomal data clearly show that the karyotype of $O$. karoensis differs significantly from that of $O$. irroratus (except for the four autosomal homologies and the $\mathrm{X}$ chromosome that is conserved in toto).

Morphometric data are discordant with cytogenetic and molecular data, appearing to uphold saundersiae as a valid taxon. Because the integrity of the cytogenetic and molecular data cannot be disputed, the morphological data need to be re-appraised. The strong correlations obtained between cranial size and shape and both relative age and taxon (Fig. 4) underline the influence of allometric paedomorphic changes in speciation (O. karoensis is diagnosed on the basis of paedomorphic traits of $O$. irroratus: small size, pallid buffy pelage and particular cranial shape traits that include proportionately narrow nasals and zygomata and wider braincase and bullae), as well as its confounding role in species recognition (young $O$. irroratus identified as 'saundersiae' exhibited phenotypic overlap with $O$. karoensis).

Putting aside ontogenetic variation, certain mature individuals (having worn molars) field-identified as 'saundersiae' (but cytogenetically and genetically identified as irroratus) remain morphologically distinct from sympatric populations of $O$. irroratus. Such dimorphism could be explained by disruptive selection on body size, pelage colour and cranial morphology, hybridization between karoensis and irroratus (but this possibility is excluded on chromosomal grounds) or by generational effects mediated by food availability and time of birth (as demonstrated by Meulepas, Leirs \& Van Dongen, 2007).

Owing to unpredictable oceanic upwelling events associated with the Agulhas current off the coast between Port Elizabeth and East London, rainfall patterns in the coastal regions of the Albany Thicket Biome are highly unpredictable (Lutjeharms, 2006). Thus, the region of its distribution where dimorphism is observed in O. irroratus (the Albany Thicket Biome) boasts the most variable (least predictable) climate within South Africa, as well as sparse, thicketdominated vegetation, and a low seasonal coefficient of variation in precipitation (transition zone between winter rainfall weather pattern of the Fynbos Biome to the west and the summer-rainfall pattern of the Grassland Biome to the north) (Fig. 1).

Perrin (1980) found that $O$. irroratus has a continuous year-round breeding season in the semi-arid Fish River Valley of the Eastern Cape, and a similar pattern (lactating females and juveniles collected in mid-winter in July) was noted during the present study at Sam Knott Nature Reserve, which occupies part of the Great Fish Valley. Available evidence suggests that breeding in $O$. irroratus may be more seasonal (limited to summer) in other parts of its range in South Africa (Taylor, 1998). A continuous breeding cycle in conjunction with unpredictable, low rainfall raises the possibility of multiple cohorts during a year having different growth and maturation rates (which may also affect pelage colour) depending on the time of birth and availability of food. Indeed, Meulepas et al. (2007) have shown that multimammate mice Mastomys natalensis in Tanzania comprise three distinct generations per year (born at times of varying food availability), with significant morphological (craniometric) divergence between them. Such a phenomenon could explain the craniometric (and colorimetric) dimorphism observed in $O$. irroratus from the semi-arid, climatically variable region of the south-eastern Cape, but not in more mesic typical habitats in more easterly and northern parts of its range.

Previous small mammal trapping records from Sam Knott Reserve in the Albany Thicket Biome (where we found 'saundersiae'-type morphs in the present study) by R. Baxter (unpubl. data) confirm that rainfall in this region is unpredictable in timing and quantity and that rainfall occurring unpredictably in the colder months initiated sporadic breeding by rodents such as dormice Graphiurus murinus, woodland mice Grammomys dolichurus and Karoo bush rats $M$. unisulcatus, thus indicating the distinct possibility of cohorts born at different times of the year having differing food availability and capable of inducing phenotypic effects. Unfortunately, sufficient trapping data in conjunction with morphological data are not available for $O$. irroratus, which is a trap-shy, rarely trapped species.

\section{Speciation within $O$. irroratus}

Our molecular data suggest the presence of at least two evolutionary species in the $O$. irroratus complex, a southern, Fynbos (C cytotype) + Albany Thicket (B cytotype) Biome species and a northern Grassland Biome species [encompassing cytotypes A1, A2, B (Zimbabwe) and C (South African Highveld)], which appear to have separated at around 1.13 million years ago (Fig. 3, Table 3 ) and that are more divergent $(P=6.4 \%)$ than $O$. karoensis from the morphologically distinct $O$. laminatus $(P=5.8 \%$; Table 3$)$.

Thus, the two phylogenetic lineages appear to coincide closely with ecological biomes and not karyotype. The $\mathrm{C}$ cytotype has arisen independently (by addition or deletions of heterochromatic arms) in both lineages. The southern clade encompasses the type locality of $O$. irroratus (Brants, 
1827) (Constantia in Cape Town, Western Cape Province; Meester et al., 1986). The northern Grassland clade includes the type localities of auratus Wroughton (1906) from Vredefort, northern Free State Province; cupreoides Roberts, 1946 from Newgate, Zoutpansberg, Limpopo Province; cupreus Wroughton (1906) from Woodbush Hills, Limpopo Province; coenosus Thomas (1918) from Kuruman, Northern Cape Province; natalensis Roberts, 1929 from Kilgobbin Farm in the Dargle Valley, KwaZulu Natal; orientalis Roberts, 1946, from Umzimkulu, East Griqualand, KwaZulu Natal; randensis Roberts, 1929, from Fontainbleu, Johannesburg, Gauteng Province. Thus, the earliest available name for the northern Grassland Biome species would be O. auratus Wroughton, 1906, from Vredefort (which has page precedence over cupreus Wroughton, 1906; Meester et al., 1986), and we recommend elevating this synonym to a recognized species having as synonyms all the other abovementioned forms.

Morphometric relationships in the dorsal skull shape of O. irroratus (Fig. 5a) mirror the molecular phylogenetic pattern, with two major groups: a Grassland Biome group and a group comprising Fynbos and Thicket Biomes. The pattern for ventral shape data (Fig. 5b) reveals the same two groups, except that the A cytotype population (Alice in the Eastern Cape) groups with geographically proximate Eastern Cape Thicket (B cytotype) and Fynbos ( $\mathrm{C}$ cytotype) Biome-populations rather than with A1- and A-cytotype populations. No A-cytotype population was included in the molecular analysis.

Within the northern lineage, two further divergent ( $P=4.5 \%$; 0.68 MYA) cyt $b$ lineages can be defined (Fig. 3, Table 3), separating populations from Zimbabwe, the South African Highveld and two Afro-temperate scarp forest relics along the southeastern African Indian Ocean escarpment (Tygerskloof and Karkloof), from localities from the Drakensberg Range (Hogsback and Kamberg) and the foothills of the Drakensberg (Dargle Valley). Thus, although Dargle is situated only a few kilometres from Karkloof, and shares the same karyotype (A2), it is phylogenetically related to Drakensberg populations rather than to Afromontane scarp forest-grassland relic patches (Karkloof and Tygerskloof). Clearly, further molecular analysis with a larger sample size and additional genetic loci is necessary to clarify this relationship.

In Africa, generally, high-latitude glaciation cycles influenced African climates from the late Pliocene, resulting in periods of aridification at 2.9-2.4 MYA, 1.8-1.6 MYA and 1.2-0.8 MYA, and frequent oscillations of glacial and interglacial periods after 1.0 MYA, culminating in the last glacial maximum at 18000 years BP (Lawes, 1990; deMenocal, 2004; Lawes et al., 2007). The current distribution of the Grassland Biome in southern Africa is highly sensitive to climate change, and extrapolations show profound shrinking of grassland at the expense of savanna (and fynbos at the expense of succulent karoo) induced by a hypothetical $2{ }^{\circ} \mathrm{C}$ increase in temperature and a $15 \%$ decrease in rainfall (Ellery, Scholes \& Mentis, 1991).

The origin of the two major clades of $O$. irroratus, as well as the separation of $O$. karoensis from $O$. laminatus, was most likely due to the onset of drier and/or warmer conditions that would have led to contraction of the temperate grasslands at the expense of savannas, and contraction of fynbos at the expense of succulent karoo (Ellery et al., 1991). Temperate-adapted species such as $O$. irroratus would have been displaced to higher elevations in both the Drakensberg and the Cape Fold Mountain Ranges, effectively isolating populations to these two distinct mountain ranges, whose higher elevations retained temperate climates. With climatic amelioration, populations would again have moved into lower altitudes. Subsequent periods of aridification or warming would have resulted in the vicariance of Drakensberg from Highveld, Afromontane and Zimbabwean highland habitats at $0.68(0.48-0.92) \mathrm{MYA}$ and the vicariance of Zimbabwe highlands from South African Highveld and Afromontane habitats at $0.5(0.32-0.70)$ MYA.

\section{Acknowledgements}

The authors thank Leigh Richards and Taryn Ralph for assistance with the field work undertaken in the Eastern Cape and Western Cape. The Curators of the following museums are thanked for access to their collections and collection databases of Otomys: Amathole Museum (Fred Kigozi), Northern Flagship Institute (Transvaal Museum) (Teresa Kearney) and Smithsonian Museum (Michael Carleton and Linda Gordon). The project was funded by grants from the National Research Foundation to P.J.T. and R.V.R.

\section{References}

Akaike, H. (1974). A new look at the statistical model identification. IEEE Trans. Automat. Control 19, 716-723.

Arctander, P. (1995). Comparison of a mitochondrial gene and a corresponding nuclear pseudogene. Proc. Roy. Soc. Lond. Ser. B 262, 13-19.

Broughton, R.E., Stanley, S.E. \& Durrett, R.T. (2000). Quantification of homoplasy for nucleotide transitions and transversions and a reexamination of assumptions in weighted phylogenetic analysis. Syst. Biol. 49, 617-627.

Contrafatto, G. (1996) Chromosomal evolution in the vlei rat Otomys irroratus. PhD thesis, University of Natal, Durban, South Africa.

Contrafatto, G., Campbell, G.K., Taylor, P.J., Goossens, V., Willan, K. \& Meester, J.A. (1992a). Genetic variation in the African rodent subfamily Otomyinae (Muridae). III. Karyotype and allozymes of the ice rat, Otomys sloggetti robertsi. Cytogenet. Cell Genet. 60, 45-47.

Contrafatto, G., Meester, J., Bronner, G., Taylor, P.J. \& Willan, K. (1992b). Genetic variation in the African rodent sub-family Otomyinae (Muridae). IV: Chromosome G-banding analysis of Otomys irroratus and Otomys angoniensis. Isr. J. Zool. 38, 277-291. 
Contrafatto, G., Meester, J.A., Willan, K., Taylor, P.J., Roberts, M.A. \& Baker, C.M. (1992c). Genetic variation in the African rodent subfamily Otomyinae (Muridae). II. Chromosomal changes in some populations of Otomys irroratus. Cytogenet. Cell Genet. 59, 293-299.

Contrafatto, G., van der Berg, J.R. \& Grace, J. (1997). Genetic variation in the African rodent sub-family Otomyinae (Muridae). 6: immuno-electro-transfer of liverproteins of some Otomys irroratus populations. Trop. Zool. 10, 157-171.

Corti, M. (1993). Geometric morphometrics: an extension of the revolution. TREE 8, 302-303.

Corti, M. \& Rohlf, F.J. (2001). Chromosomal speciation and phenotypic evolution in the house mouse. Biol. J. Linn. Soc. 73, 99-112.

Cunningham, C.W. (1997). Is congruence between data partitions a reliable predictor of phylogenetic accuracy? Empirically testing an iterative procedure for choosing among phylogenetic methods. Syst. Biol. 46, 464-478.

Denys, C. (2003). Evolution du genre Otomys (Rodentia: Muridae) au Plio-Pléistocène d'Afrique orientale et australe. In Advances in palaeontology "Henth to Pantha". Memorial Volume C: 75-84. Radulescu, C. \& Petculescu, P.M.S. (Eds).

Drummond, A.J. \& Rambaut, A. (2006a). BEAST v. 1.4.Bayesian evolutionary analysis sampling trees. http:// evolve.zoo.ox.uk/beast/. Accessed 25 August 2008.

Drummond, A.J. \& Rambaut, A. (2006b). BEAUti v. 1.4. Bayesian evolutionary analysis utility. http://evolve.zoo. ox.uk/beast/. Accessed 25 August 2008.

Ducroz, J.-F., Volobouev, V. \& Granjon, L. (2001). An assessment of the systematics of arvicanthine rodents using mitochondrial DNA sequences: evolutionary and biogeographical implications. J. Mammal. Evol. 8, 173-206.

Ellery, W.N., Scholes, R.J. \& Mentis, M.T. (1991). An initial approach to predicting the sensitivity of the grassland biome to climate change. S. Afr. J. Sci. 87, 499-503.

Engelbrecht, A., Dobigny, G. \& Robinson, T.J. (2006). Further insights into the ancestral murine karyotype: the contribution of the Otomys - Mus comparison using chromosome painting Cytogenet. Genome Res. 112, 126-130.

Esposti, M.D., De Vries, S., Crimi, M., Ghelli, A., Paternello, T. \& Meyer, A. (1993). Mitochondrial cytochrome $b$ : evolution and structure of the protein. Biochim. Biophys. Acta 1143, 243-271.

Felsenstein, J. (1981). Evolutionary trees from DNA sequences: a maximum likelihood approach. J. Mol. Evol. 17, 368-376.

Felsenstein, J. (1985). Confidence estimates on phylogenies: an approach using bootstrap. Evolution 39, 783-791.

Felsenstein, J. (1988). Phylogenies from molecular sequences: inference and reliability. Annu. Rev. Genet. 22, $521-565$.
Gu, X., Fu, Y.-X. \& Li, W.-H. (1995). Maximum likelihood estimation of the heterogeneity of substitution rates among nucleotide sites. Mol. Biol. Evol. 12, 546-557.

Hasegawa, M., Kishino, H. \& Yano, T. (1985). Dating the human-ape splitting by a molecular clock of mitochondrial DNA. J. Mol. Evol. 22, 160-174.

Hillis, D.M. (1991). Discriminating between phylogenetic signal and random noise in DNA sequences. In Phylogenetic analysis of DNA sequences: 278-294. Miyamoto, M.M. \& Cracraft, J. (Eds). New York: Oxford University Press.

Hillis, D.M. (1995). Approaches for assessing phylogenetic accuracy. Syst. Biol. 44, 3-16.

Hillis, D.M., Huelsenbeck, J.P. \& Cunningham, C.W. (1994). Application and accuracy of molecular phylogenies. Science 264, 671-677.

Huelsenbeck, J.P. (2002). Testing a covariotide model of DNA substitution. Mol. Biol. Evol. 19, 698-707.

Huelsenbeck, J.P. \& Rannala, B. (1997). Phylogenetic methods come of age: testing hypotheses in an evolutionary context. Science 276, 227-232.

Huelsenbeck, J.P. \& Ronquist, F. (2001). MRBAYES. Bayesian inference of phylogeny. Bioinformatics 17, 754-755.

Huelsenbeck, J.P. \& Ronquist, F. (2003). MrBayes: A program for the Bayesian inference of phylogeny, 3.0. New York: Rochester.

Irwin, D.M., Kocher, T.D. \& Wilson, A.C. (1991). Evolution of the cytochrome $b$ gene of marine mammals. J. Mol. Evol. 32, 128-144.

Jansa, S.A., Barker, F.K. \& Heaney, L.R. (2006). The pattern and timing of diversification of Philippine endemic rodents: evidence from mitochondrial and nuclear gene sequences. Syst. Biol. 55, 73-88.

Kelchner, S.A. \& Thomas, M.A. (2006). Model use in phylogenetics: nine key questions. TREE 22, 87-94.

Kluge, A.G. \& Farris, J.S. (1969). Quantitative phyletics and the evolution of anurans. Syst. Zool. 18, 1-32.

Lanave, C., Preparata, C., Saccone, C. \& Serio, G. (1984). A new method for calculating evolutionary substitution rates. J. Mol. Evol. 20, 86-93.

Lawes, M.J. (1990). The distribution of the Samango Monkey (Cercopithecus mitis erythrarchus Peters, 1852 and Cercopithecus mitis labiatus I. Geoffroy, 1843) and forest history in southern Africa. J. Biogeogr. 17, 669-680.

Lawes, M.J., Eeley, H.A.C., Findlay, N.J. \& Forbes, D. (2007). Resilient forest faunal communities in South Africa: a legacy of palaeoclimatic change and extinction filtering? J. Biogeogr. 34, 1246-1264.

Lutjeharms, J.R.E. (2006). The Agulhas current. Berlin: Springer.

Maddison, W.P. \& Maddison, D.R. (1992). MacClade analysis of phylogeny and character evolution, version 3. Sunderland, MA: Sinauer Associates. 
Maree, S. (2002). Phylogenetic relationships and mitochondrial DNAsequence evolution in the African rodent subfamily Otomyinae (Muridae). PhD thesis, University of Pretoria, Pretoria.

Matthee, C.A. \& Davis, S.K. (2001). Molecular insights into the evolution of the Family Bovidae: a nuclear perspective. Mol. Biol. Evol. 18, 1220-1230.

Meester, J., Taylor, P.J., Contrafatto, G.-C., Campbell, G.K., Willan, K., Lamb, J.M. \& Pillay, N. (1992). Chromosomal speciation in Southern African Otomyinae (Rodentia: Muridae): a review. Durban Mus. Novit. 17, 58-63.

Meester, J.A.J., Rautenbach, I.L., Dippenaar, N.J. \& Baker, C.M. (1986). Classification of Southern African mammals. Transv. Mus. Monogr. 5, 1-359.

de Menocal, P.B. (2004). African climate change and faunal evolution during the Pliocene-Pleistocene. Earth Plant. Sci. Lett. Front. 220, 3-24.

Meulepas, G., Leirs, H. \& Van Dongen, S. (2007). The importance of developmental instability and canalization regarding the development of the skull of the multimammate rat (Mastomys natalensis). Abstract, 10th International African Small Mammal Symposium, Abomey-Calavi, Benin, 20-25 August 2007.

Mucina, L. \& Rutherford, M.C. (2006). The vegetation of South Africa, Lesotho and Swaziland. Pretoria: South African National Biodiversity Institute.

Musser, G.G. \& Carleton, M.D. (2005). Family Muridae. In Mammal species of the world. A taxonomic and geographic reference, 3rd edn: 501-755. Wilson, D. \& Reeder, D. (Eds). Washington, DC: Smithsonian Institution Press.

Olson, D.M., Dinerstein, E. \& Wikramanayake, E.D., et al. (2001). Terrestrial ecoregions of the world: a new map of life on earth. Bioscience 51, 933-938.

Perrin, M.R. (1980). The breeding strategies of two coexisting rodents, Rhabdomys pumilio (Sparrman 1784) and Otomys irroratus (Brants 1827). Acta Oecol. Gen. 1, 383-410.

Pillay, N., Willan, K. \& Meester, J. (1995). Post-zygotic reproductive isolation in two populations of the African vlei rat Otomys irroratus. Acta Theriol. 40, 69-76.

Posada, D. \& Crandall, K.A. (1998). MODELTEST: testing the model of DNA substitution. Bioinformatics 14, 817-818.

Rambau, R.V., Elder, F.F.B. \& Robinson, T.J. (2001). Chromosomal evolution in the vlei rat, Otomys irroratus (Muridae: Otomyinae): a compound chromosomal rearrangement separates two major cytogenetic groups. Cytogenet. Cell Genet. 93, 253-257.

Rambau, R.V., Harrison, W.R., Elder, F.F.B. \& Robinson, T.J. (1997). Chromosomes of Brants' whistling rat and genome conservation in the Otomyinae revealed by G-banding and fluorescence in situ hybridization. Cytogenet. Cell Genet. 78, 216-220.

Rambaut, A. \& Drummond, A.J. (2005). TRACER v1.2. MCMC Trace Analysis Tool. http://evolve.zoo.ox.uk/ beast/. Accessed 25 August 2008.
Rens, W., Fu, B., O’Brien, P.C.M. \& Ferguson-Smith, M.A. (2006). Cross-species chromosome painting. Nat. Protoc. 1, 783-790.

Roberts, A. (1931). New forms of South African mammals. Ann. Transv. Mus. 14, 221-236.

Robinson, T.J. \& Elder, F.F.B. (1987). Extensive genome reorganization in the African rodent genus Otomys. J. Zool. (Lond.) 211, 735-745.

Rodriguez, F.L., Oliver, J., Martin, L. \& Medina, J.R. (1990). The general stochastic model of nucleotide substitution. $J$ Theor. Biol. 142, 485-501.

Rohlf, F.J. (1997a). tpsRegr, version 1.13. State University of New York at Stony Brook.

Rohlf, F.J. (1997b). tpsRelw, version 1.16. State University of New York at Stony Brook.

Rohlf, F.J. (1997c). NTSYS-pc, version 2.01h. Setauket, NY: Exeter Software.

Rohlf, F.J. (1998a). tpsDig, version 1.18. State University of New York at Stony Brook.

Rohlf, F.J. (1998b). On applications of geometric morphometrics to studies of ontogeny and phylogeny. Syst. Biol. 47, 147-158.

Rohlf, F.J. \& Marcus, L.F. (1993). A revolution in morphometrics. TREE 8, 129-132.

Rutherford, M.C. \& Westphal, R.H. (1994). Biomes of southern Africa: an objective characterization. Memoirs of the botanical Survey of South Africa No. 63. Pretoria: National Botanical Institute.

Seabright, M. (1971). A rapid banding technique for human chromosomes. Lancet 2, 971-972.

Slifer, E.H. (1934). Insect development: VI. The behavior of grasshopper embryos in anisotonic, balanced salt solution. J. Exp. Zool. 67, 137-157.

Steppan, S.J., Zawadski, C. \& Heaney, L.R. (2003). Molecular phylogeny of the endemic Philippine rodent Apomys (Muridae) and the dynamics of diversification in an oceanic archipelago. Biol. J. Linn. Soc. 80, 699-715.

Sumner, A.T. (1972). A simple technique for demonstrating centromeric heterochromatin. Exp. Cell Res. 75, 304-306.

Swofford, D.L. (2002). PAUP*. Phylogenetic analysis using parsimony (* and other methods), 4b10. Sunderland, MA: Sinauer Associates.

Swofford, D.L., Olsen, G.J., Waddell, P.J. \& Hillis, D.M. (1996). Phylogenetic inference. In Molecular systematics: 407-514. Hillis, D.M., Moritz, C. \& Mable, B.K. (Eds). Sunderland, MA: Sinauer Associates.

Tamura, K. \& Nei, M. (1993). Estimation of the number of nucleotide substitutions in the control region of mitochondrial DNA in humans and chimpanzees. Mol. Biol. Evol. 10, 512-526.

Taylor, P.J. (1998). The smaller mammals of KwaZulu-Natal. Pietermaritzburg, South Africa: University of Natal Press.

Taylor, P.J. (2000). Patterns of chromosomal variation in southern African rodents. J. Mammal. 81, 317-331. 
Taylor, P.J., Campbell, G.K., Van Dyk, D., Meester, J. \& Willan, K. (1992). Genetic variation in the African vlei rat Otomys irroratus. Israel J. Zool. 38, 293-305.

Taylor, P.J., Contrafatto, G. \& Willan, K. (1994). Climatic correlates of chromosomal variation in the African vlei rat, Otomys irroratus. Mammalia 58, 623-634.

Taylor, P.J., Denys, C. \& Mukerjee, .M. (2004a). Phylogeny of the African murid tribe Otomyini (Rodentia), based on morphological and allozyme evidence. Zool. Scr. 33, 389-402.

Taylor, P.J., Kumirai, A. \& Contrafatto, G. (2004b). Geometric morphometric analysis of adaptive cranial evolution in southern African laminate-toothed rats (Family: Muridae, Tribe: Otomyini). Durban Mus. Novit. 29, 104-109.

Taylor, P.J., Kumirai, A. \& Contrafatto, G. (2005). Species with fuzzy borders: the taxonomic status and species limits of Saunders' vlei rat, Otomys saundersiae Roberts (Rodentia: Muridae: Otomyini). Mammalia 69, 297-322.

Taylor, P.J., Meester, J. \& Kearney, T. (1993). The taxonomic status of Saunder's vlei rat, Otomys saundersiae Roberts (Rodentia: Muridae: Otomyinae). J. Afr. Zool. 107, 1-26.

Telenius, H., Pelmear, A.H., Tunnacliffe, A., Carter, N.P., Behmel, A., Fergusonsmith, M.A, Nordenskjold, M., Pfragner, .R. \& Ponder, B.A.J. (1992). Cytogenetic analysis by chromosome painting using DOP-PCR amplified flow-sorted chromosomes. Genes Chromosom. Cancer 4, 257-263.

Thompson, J.D., Gibson, T.J., Plewniak, F., Jeanmougin, .F. \& Higgins, D.G. (1997). The ClustalX windows interface: flexible strategies for multiple sequence alignment aided by quality analysis tools. Nucleic Acids Res. 25, 4876-4882.
Williams, P.L. \& Fitch, W.M. (1990). Phylogeny determination using dynamically weighted parsimony method. In Molecular evolution: Computer analysis of protein and nucleic acid sequences: 615-627. Doolittle, R.F. (Ed.). Methods Enzymol. 183.

Yang, Z. (1994). Maximum likelihood phylogenetic estimation from DNA sequences with variable rates over sites: approximate methods. J. Mol. Evol. 39, 306-314.

\section{Supporting Information}

Additional Supporting Information may be found in the online version of this article:

Figure S1. A summary of the FISH results indicating mapping of the complete suite of $M$. unisulcatus whole chromosome probes $(\mathrm{N}=13$ plus the $\mathrm{X})$ to the $\mathrm{G}$-banded metaphase chromosomes of $O$. irroratus $(2 \mathrm{n}=28)$ and $O$. karoensis $(2 \mathrm{n}=28)$. (a) G-banded karyotype of $O$. irroratus (DM8388) with the 35 regions of homology identified by the $M$. unisulcatus chromosomes. (b) G-banded karyotype of $O$. karoensis (DM 8396) with the 34 regions of homology identified by the $M$. unisulcatus chromosomes. Vertical lines indicate the extent of the conserved homology identified by respective $M$. unisulcatus chromosomes which are represented by adjacent numbers. The asterisk indicates heterochromatic regions which were not hybridized.

Please note: Wiley-Blackwell are not responsible for the content or functionality of any supporting materials supplied by the authors. Any queries (other than missing material) should be directed to the corresponding author for the article. 